\title{
POLA ASUH DEMOKRATIF MEMBANTU KEMAMPUAN PERKEMBANGAN PADA ANAK GEMUK USIA 2-5 TAHUN
}

(Democratic Parenting Patterns Help The Development Skills In Obese Children Age 2-5 Years)

\author{
Wulandari $^{1}$, Mei Neni Sitaresmi $^{2}$, Sulistyaningsih ${ }^{2}$ \\ Dosen Program Studi D3 Kebidanan Fakultas Keperawatan dan IImu Kesehatan Universitas \\ Muhammadiyah Banjarmasin', Dosen Universitas 'Aisyiyah Yogyakarta² \\ Email:Wulandari.f4@gmail.com
}

\begin{abstract}
ABSTRAK
Latar belakang: Pola asuh demokratis yang dilakukan orang tua dapat membantu anak melakukan tugas perkembangan sesuai usianya. Tujuan: Penelitian ini bertujuan untuk mengetahui jenis pola asuh yang dilakukan ibu serta perkembangan pada anak gemuk usia 2-5 tahun.

Metode: Jenis penelitian observasional dengan desain cross sectional. Sampel penelitian seluruh anak gemuk usia 2-5 tahun di wialayah kerja Puskesmas Kalasan ( $n=160)$.

Hasil: Pola asuh demokratif memiliki nilai OR (2.37 [0.69-8.15]). Nilai R2 sebesar 0.147. Kesimpulan: Pola asuh demokratif menurunkan risiko terjadinya suspek perkembangan sebesar 2 kali. Stimulasi, pola asuh, umur dan pendidikan ibu memiliki peluang terhadap terjadinya suspek perkembangan anak gemuk usia 2-5 tahun sebesar $14.7 \%$.
\end{abstract}

Kata Kunci: pola asuh, perkembangan, anak gemuk 2-5 tahun.

\section{ABSTRACT}

Background : Democratic parenting by parents can help children carry out developmental tasks according to their age. This study aims to determine the type of parenting performed by mothers and the development of obese children aged 2-5 years.

Method: This study was an observational study with a cross-sectional design. The study sample was all obese children aged 2-5 years in the Kalasan Primary Health care $(n=160)$.

Result and discussion: Democratic parenting has an OR value (2.37 [0.69-8.15]). The R2 value of 0.147. The democratic parenting reduces the risk of developing suspects by two times. Stimulation, upbringing, age, and education of the mother have an opportunity for the occurrence of suspected development of obese children aged $2-5$ years by $14.7 \%$.

Keyword : parenting, development, fat children 2-5 years.

\section{PENDAHULUAN}

Kemenkes RI (2015) memaparkan data balita gemuk di Indonesia pada tahun 2013 sebesar $11,8 \%$, Daerah Istimewa Yogyakarta sebanyak 10,3\% dan Kabupaten Sleman sebanyak 12,1\%.

Gaya yang digunakan orang tua saat berinteraksi, mendisiplinkan serta melakukan pengasuhan bersama (Benzies et al dalam Santrock, 2011b) memperlihatkan kualitas pengasuhan yang diberikan. Pola asuh demokratis yang dilakukan orang tua dapat membantu anak melakukan tugas perkembangan sesuai usianya (Rachmayanti dan Pudjiastuti, 2012). Pola asuh otoriter memiliki peluang 27 kali untuk terjadinya sosialisasi anak kurang dibandingkan dengan pola asuh demokratis (Erwanto, 2014).

Pendidikan dan pengetahuan ibu yang lebih baik meningkatkan kualitas pengasuhan (Chandriyani, 2009; Yulita, 2014). Orang tua yang memiliki anak 2 atau lebih menyebabkan perhatian orang tua terbagi pada anak-anaknya (Santrock, 2011b). Kondisi dan sifat dari pekerjaan ibu mempengaruhi kualitas pengasuhan anak (Thompson dalam Santrock, 2011b). Usia ibu muda dapat mempengaruhi sumber daya yang tersedia untuk anak (Blachman \& Lukacs, 2009).

Penelitian ini bertujuan untuk mengetahui hubungan jenis pola asuh dengan perkembangan pada anak gemuk usia 2-5 tahun. Penelitian ini 
dapat digunakan untuk mengembangkan asuhan kebidanan pada balita dan anak pra sekolah yang mengalami kegemukan.

\section{METODE PENELITIAN}

Penelitian ini merupakan penelitian analitik observasional dengan rancangan cross sectional. Sampel penelitian adalah seluruh anak gemuk usia 2-5 tahun di wialayah kerja Puskesmas Kalasan sebanyak 160 anak. Penelitian dilakukan dengan cara melakukan penilaian jenis pola asuh yang dilakukan orang tua dengan kuisioner Parenting Style Questionnaire (PSQ) dan perkembangan anak menggunakan Denver II.

Variabel Independen dalam penelitian ini terdiri dari pola asuh. Variabel Dependen dalam penelitian ini adalah perkembangan anak gemuk. Variabel Pengganggu dalam penelitian ini terdiri dari umur, pendidikan, pekerjaan orang tua.

Analisis bivariat dalam penelitian ini menggunakan uji Spearman Rank ( $\rho)$ untuk variabel berskala ordinal-ordinal seperti analisis hubungan, pola asuh, umur ibu, pendidikan dengan perkembangan. Analisis data untuk variabel dengan skala nominal ordinal seperti hubungan pekerjaan dengan perkembangan menggunakan uji koefisien kontingensi (C) (Sastroasmoro dan Ismael, 2014). Analisis multivariat dalam penelitian ini digunakan untuk mengetahui besarnya korelasi antara variabel pola asuh, umur, pendidikan, pekerjaan orang tua dengan perkembangan. Uji statistik yang digunakan adalah regresi logistik dengan tingkat kemaknaan $\alpha=0,05$ dan interval kepercayaan $95 \%$.

Penelitian ini telah melalui proses uji kelayakan oleh Lembaga Pengembangan Penelitian dan Pengabdian Masyarakat (LP3M) Universitas 'Aisyiyah Yogyakarta. Responden telah diberikan informasi mengenai tujuan penelitian, prosedur pelaksanaan, manfaat penelitian dan kerahasiaan responden dan menyatakan kesediaan sebagai responden. Peneliti menjamin kerahasiaan informasi responden dengan mencantumkan kode untuk nama responden pada lembar penelitian. Penelitian ini tidak memiliki risiko yang membahayakan dan merugikan bagi responden. Penelitian ini memberikan manfaat berupa informasi tentang perkembangan serta bentuk stimulasi dan gaya pengasuhan yang tepat untuk anak. Penelitian ini dilakukan dengan memenuhi prinsip keadilan (tidak membedakan perlakuan antar responden), manfaat dan menghormati orang lain.

\section{HASIL DAN PEMBAHASAN}

\section{Sub Bab 1}

\section{Pola Asuh Orang Tua}

Pola asuh orang tua yang memiliki anak gemuk usia 2-5 tahun digambarkan pada tabel 1 berikut.

\begin{tabular}{clcc}
\hline Variabel & Kategori & $\mathrm{n}$ & $\%$ \\
\hline Pola asuh & Permisif & 13 & 8.1 \\
& Otoritater & 16 & 10.0 \\
& Demokratif & 131 & 81.9 \\
\hline
\end{tabular}

Hasil penelitian pada tabel 1 menunjukkan bahwa sebagian besar ibu memberikan pola asuh demokratif. Pola asuh demokratif adalah pola asuh yang memberikan dorongan pada anak untuk mandiri namun tetap menerapkan berbagai batasan yang akan mengontrol perilaku mereka. Pola asuh ini memprioritaskan kepentingan anak tetapi tidak ragu untuk mengendalikan mereka. Orang tua bersikap realistis, mendengarkan dan menerima kemampuan anak (Afriani et al, 2012).

Pola asuh demokratif dicirikan dengan adanya tuntutan dari orang tua disertai dengan komunikasi terbuka antara orang tua dan anak. Orang tua sangat memperhatikan kebutuhan anak dan mencukupinya dengan mempertimbangkan faktor kepentingan dan kebutuhan (Stansbury, et al, 2012).

Teknik-teknik asuhan orang tua yang demokratif akan menumbuhkan keyakinan dan kepercayaan diri maupun mendorong tindakantindakan mandiri dan bertanggung jawab (Afriani et al, 2012). Pola asuh demokratif dapat membuat anak mudah berinteraksi dengan teman sebayanya, mampu menghadapi stress, mempunyai minat terhadap hal-hal yang baru, kooperatif dengan orang dewasa, penurut, patuh, dan berorientasi pada prestasi (Onder \& Gulay, 2009).

Hasil penelitian pada tabel 1 menunjukkan bahwa masih ada ibu yang memberikan pola asuh otoriter dan permisif. Pola asuh otoriter dapat mengakibatkan anak menjadi penakut, pencemas, menarik diri dari pergaulan, kurang adaptif, mudah curiga pada orang lain dan mudah stress. Orang tua yang melakukan pengasuhan otoriter akan membuat anak tidak percaya diri, pendiam, tertutup, tidak berinisiatif, gemar menentang, suka melanggar norma, kepribadian lemah dan seringkali menarik diri dari lingkungan sosialnya, bersikap menunggu dan tak dapat merencanakan sesuatu dengan baik (Santrock, 2011b).

Pola asuh permisif dapat mengakibatkan anak agresif, tidak patuh pada orang tua, merasa berkuasa dan kurang mampu mengontrol diri. Karakter anak dengan pola asuh orang tua 
demikian menjadikan anak impulsif, manja, kurang mandiri, mau menang sendiri, kurang percaya diri dan kurang matang secara sosial. Anak merasa kurang perhatian, merasa tidak berarti, rendah diri, nakal, memiliki kemampuan sosialisasi yang buruk, kontrol diri buruk, salah bergaul, kurang menghargai orang lain dan agresif (Onder \& Gulay, 2009).

\section{Perkembangan Anak Gemuk Usia 2-5 Tahun}

Perkembangan anak gemuk usia 2-5 tahun digambarkan pada tabel 2 berikut ini.

Tabel 2 Ditribusi frekuensi berdasarkan perkembangan anak gemuk

\begin{tabular}{cccc}
\hline Variabel & Kategori & $\mathrm{n}$ & $\%$ \\
\hline Perkembangan & Suspek & 37 & 23.1 \\
& Normal & 123 & 76.9 \\
\hline
\end{tabular}

Tabel 2 menunjukkan bahwa sebagian besar anak gemuk mengalami perkembangan sesuai tahapannya dan sebesar $23.1 \%$ anak gemuk usia 2-5 tahun mengalami suspek perkembangan pada sektor motorik kasar, motorik halus, bahasa dan personal sosial. Anak dikatakan terjadi suspek perkembangan apabila terdapat 2 atau lebih peringatan atau 1 atau lebih keterlambatan (Soetjiningsih dan Ranuh, 2012).

Kegemukan dan obesitas memiliki dampak yang buruk pada perkembangan anak selanjutnya, termasuk penurunan kepercayaan diri dan hubungan psikososial (Griffiths et al, 2010). Beberapa penelitian menyebutkan bahwa anak obesitas memiliki perkembangan sosial emosional dan kebiasaan yang buruk (Drukker et al, 2009;
Griffiths et al, 2011). Perkembangan fisik, pengetahuan (Lopes et al, 2012), bahasa (Cawley \& Spiess, 2008; Kamijo et al, 2012) dan menjadi rentan pada satu atau lebih domain (Pearce et al, 2016).

Morano et al (2011) menyebutkan bahwa anak gemuk memiliki keterampilan motorik kasar kurang dibandingkan anak dengan berat badan normal. Sejalan dengan pendapat Pearce et al (2016) menyebutkan bahwa anak gemuk berisiko sebesar 1.97 kali untuk terjadi suspek perkembangan motorik dan berpeluang untuk terjadi suspek perkembangan bahasa sebesar 0.73 kali.

Obesitas pada usia 5 tahun menurunkan kemampuan motorik anak pada usia 5-10 tahun (Cheng et al, 2016). Kemampuan motorik anak prasekolah dengan obesitas menurun $20 \%$, sedangkan pada anak Taman Kanak-kanak (TK, penurunan kemampuan motorik anak obesitas sebesar 10\%. Keterampilan motorik kasar dan halus selain melompat pada anak-anaktidak terkait dengan BMI z-skor dan kegemukan. Keterampilan motorik berhubungan negatif dengan kegemukan (Castetbon \& Andreyeva, 2012)

\section{Hubungan pola asuh orang tua dan perkembangan anak gemuk usia 2-5 tahun}

Hubungan antara pola asuh orang tua dan perkembangan anak gemuk usia 2-5 tahun digambarkan pada tabel 3 .

\begin{tabular}{|c|c|c|c|c|c|c|c|c|}
\hline \multirow{3}{*}{ Variabel } & \multicolumn{4}{|c|}{ Perkembangan } & \multicolumn{2}{|c|}{ Total } & \multirow{3}{*}{$\begin{array}{c}p- \\
\text { value }\end{array}$} & \multirow{3}{*}{$\begin{array}{c}\text { Koefisie } \\
\mathrm{n} \\
\text { korelasi } \\
(\rho)\end{array}$} \\
\hline & \multicolumn{2}{|c|}{ Suspek } & \multicolumn{2}{|c|}{ Normal } & \multirow[b]{2}{*}{$\mathrm{N}$} & \multirow{2}{*}{$\%$} & & \\
\hline & $\mathrm{N}$ & $\%$ & $\mathrm{~N}$ & $\%$ & & & & \\
\hline \multicolumn{9}{|l|}{ Pola asuh } \\
\hline Permisif & 6 & 16.2 & 7 & 5.7 & 13 & 8.1 & 0.00 & $\rho=$ \\
\hline Otoriter & 6 & 16.2 & 10 & 8.1 & 16 & 10.0 & 9 & 0.207 \\
\hline Demokratif & 25 & 67.6 & 106 & 86.2 & 131 & 81.9 & & \\
\hline
\end{tabular}

Tabel 3 menjelaskan bahwa terdapat hubungan yang signifikan antara pola asuh dan perkembangan $(p=0.009)$ dengan kekuatan hubungan lemah $(\rho=0.207)$. Pola asuh yang tepat dapat membantu anak menjadi percaya diri, kreatif, meningkatkan kompetensi sosial, kemampuan komunikasi, kognitif dan kecerdasan majemuk (Soetjiningsih dan Ranuh, 2012).

Kewajiban orang tua adalah memberikan pengasuhan yang positif kepada anaknya (Kochanska et al dalam Santrock, 2011b). Penelitian Fatimah dalam Kusumanegara (2015) menunjukkan bahwa pola asuh orang tua yang baik akan membentuk pribadi anak yang baik. Ekspresikan kasih sayang (memeluk, mencium, memberi pujian), melatih emosi dan melakukan pengontrolan pada anak memberikan hasil positif yaitu anak merasa diperhatikan dan akan lebih percaya diri. Penelitian Pradipta (2014) menunjukkan bahwa adanya pola interaksi yang baik antara orang tua dan anak juga akan menimbulkan balasan yang baik dari anak.

Pemenuhan kebutuhan dasar yang dibutuhkan oleh anak dapat membantu tumbuh kembang menjadi optimal (Jaenudin, 2000). Kebutuhan tersebut meliputi kebutuhan fisik biomedis (asuh), kebutuhan emosi/kasih sayang (asih) berupa ikatan erat, mesra, serta selaras antara ibu/orangtua dan anak, dan kebutuhan akan 
stimulus mental (Asah) merupakan cikal bakal proses pembelajaran (pendidikan dan pelatihan).

Anak merupakan amanah dari Allah Swt yang diberikan kepada setiap orangtua, anak juga buah hati, anak juga cahaya mata,tumpuan harapan serta kebanggaan keluarga. Anak adalah generasi mendatang yang mewarnai masa kini dan diharapkan dapat membawa kemajuan dimasa mendatang. Anak juga merupakan ujian bagi setiap orangtua sebagaimana disebutkan dalam Al-Qur"an surah Al-Anfal ayat 28 yang berbunyi :

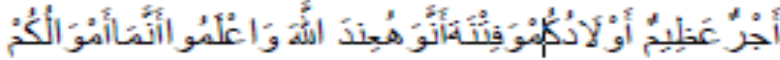

Artinya :"Dan ketahuilah bahwa hartamu dan anak-anakmu itu hanyalah sebagai cobaan dan sesungguhnya disisi Allahlah pahala yang besar." (QS.Al-Anfal ayat 28).

Ayat tersebut diatas, menjelaskan salah satu ujian yang diberikan Allah kepada orang tua adalah anak-anak mereka. Itulah sebabnya setiap orang tua hendaklah benar-benar bertanggung jawab terhadap amanah yang diberikan Allah Swt sekaligus menjadi batu ujian yang harus dijalankan. Jika anak yang di didik mengikuti ajaran Islam maka orang tua akan memperoleh ganjaran pahala yang besar dari hasil ketaatan mereka.

Pemberian pola asuh yang tidak tepat selama masa perkembangan dapat menurunkan kemampuan bahasa anak. Anak lebih cenderung mengalami stress dan tidak dapat membuat keputusan untuk diri sendiri. Perilaku memanjakan dari orang tua, tidak memberikan arah dan bimbingan, membuat anak terhambat dalam mengembangkan nilai moral (Bornstein \& Bornstein, 2014).

Takahasi et al (2015) menjelaskan bahwa pola asuh yang baik dapat meningkatkan kemampuan personal anak usia 2-5 tahun, begitu pula sebaliknya. Pola asuh otoriter dan permisif cendrung memberikan efek negatif terhadap kemampuan personal sosial anak. Kelompok etnis di Asia cenderung menerapkan pola asuh otoriter untuk mendapatkan hasil yang positif.h.

\section{Hubungan umur, pendidikan dan pekerjaan ibu dengan perkembangan}

Hubungan umur, pendidikan dan pekerjaan ibu dengan perkembangan anak gemuk usia 2-5 tahun digambarkan pada tabel 4 berikut

Tabel 4 Tabulasi silang variabel confounding dengan perkembangan

\begin{tabular}{|c|c|c|c|c|c|c|c|c|}
\hline \multirow{3}{*}{ Variabel } & \multicolumn{4}{|c|}{ Perkembangan } & \multicolumn{2}{|c|}{ Total } & \multirow{3}{*}{$p$-value } & \multirow{3}{*}{$\begin{array}{c}\text { Koefisien } \\
\text { korelasi }(\mathrm{C} / \rho)\end{array}$} \\
\hline & \multicolumn{2}{|c|}{ Suspek } & \multicolumn{2}{|c|}{ Normal } & \multirow{2}{*}{$\mathrm{N}$} & \multirow{2}{*}{$\%$} & & \\
\hline & $\mathrm{n}$ & $\%$ & $\mathrm{n}$ & $\%$ & & & & \\
\hline \multicolumn{9}{|l|}{ Umur ibu } \\
\hline Dewasa awal & 17 & 45.9 & 88 & 71.5 & 105 & 65.5 & 0.004 & $\rho=-0.227$ \\
\hline Dewasa madya & 20 & 54.1 & 35 & 28.5 & 55 & 34.4 & & \\
\hline \multicolumn{9}{|l|}{ Pendidikan } \\
\hline Pendidikan rendah & 25 & 67.6 & 50 & 40.7 & 75 & 46.9 & 0.004 & $\rho=0.227$ \\
\hline Pendidikan tinggi & 12 & 32.4 & 73 & 59.3 & 85 & 53.1 & & \\
\hline \multicolumn{9}{|l|}{ Pekerjaan } \\
\hline Bekerja & 16 & 43.2 & 54 & 43.9 & 70 & 43.8 & 0.944 & $C=0.006$ \\
\hline Tidak bekerja & 21 & 56.8 & 69 & 56.1 & 90 & 56.2 & & \\
\hline
\end{tabular}

Tabel 4 menjelaskan bahwa terdapat hubungan yang signifikan antara umur ibu dan perkembangan $(p=0.004)$ dengan kekuatan hubungan lemah dan arah hubungan negatif $(\rho=-$ 0.227). Artinya, umur dewasa madya lebih berisiko terjadi suspek perkembangan dibandingkan dengan umur dewasa awal.

Umur merupakan indikator kedewasaan seseorang, semakin bertambah umur semakin bertambah pengetahuan dan pengalaman yang dimiliki mengenai perilaku yang sesuai untuk mendidik anak. Saadah dalam Yurika (2009) menyebutkan bahwa faktor umur ibu berkontribusi terhadap perkembangan balita. Anak-anak dengan orang tua usia muda akan mendapatkan pengawasan yang lebih longgar karena dalam diri orang tua usia muda cenderung memiliki sifat toleransi yang tinggi dan memaklumi terhadap anak. Usia ibu muda juga dapat mempengaruhi sumber daya yang tersedia untuk anak (Blachman \& Lukacs, 2009).Hasil penelitian diatas tidak sejalan dengan pendapat Hurlock (1999) bahwa semakin dewasa umur seseorang semakin matang dalam mengasuh anak. pemberian stimulasi yang baik serta pola asuh demokratif oleh orang tua dapat meningkatkan kemampuan personal sosial anak gemuk.

Tabel 4 menjelaskan bahwa terdapat hubungan yang signifikan antara pendidikan ibu dan perkembangan $(p=0.004)$ dengan kekuatan hubungan lemah dan arah hubungan positif $(\rho=0.227)$. Kualifikasi pendidikan ibu yang 
semakin tinggi membantu anak melaksanakan tugas perkembangan.

Orang tua yang memiliki tingkat pendidikan dan wawasan yang tinggi akan memperhatikan dan merawat anak sesuai dengan usia perkembangannya, melakukan penyesuaian pribadi dan sosial yang lebih baik, sehingga anak memiliki pandangan positif terhdap orang lain dan masyarakat. Pendidikan dan pengetahuan ibu yang lebih baik meningkatkan kualitas pengasuhan dan membantu anak mencapai tahapan perkembangannya (Chandriyani, 2009; Yulita, 2014).

Penelitian Sanders \& Morawska dalam Yusuf (2013) menunjukkan bahwa ketika ibu memiliki pengetahuan yang lebih tinggi tentang perkembangan anak, keterampilan pengasuhan menjadi lebih baik. Anak-anak mereka memiliki kemampuan kognitif yang lebih tinggi dan sedikit masalah perilaku.

Tabel 4 menyimpulkan bahwa pekerjaan tidak berhubungan secara signifikan dengan perkembangan anak gemuk usia 2-5 tahun. Santrock (2011b) menjelaskan, selain pekerjaan faktor keluarga yang mempengaruhi kemampuan perkembangan anak meliputi pendapatan keluarga, pendidikan orang tua, jumlah saudara, jenis kelamin dalam keluarga, stabilitas rumah tangga, kepribadian ayah/ ibu, dan adat istiadat.

Perkembangan anak ditentukan oleh berbagai fungsi lingkungan yang saling berinteraksi dengan individu, melalui pendekatan yang sifatnya memberikan perhatian, kasih sayang dan peluang untuk mengaktualisasikan diri sesuai dengan taraf dan kebutuhan perkembangannya (Horowitz, dkk dalam Novita 2013).

Tabel 5 Analisis Multivariat antara Variabel Bebas, Variabel Terikat dan Variabel Confounding

\begin{tabular}{|c|c|c|c|c|}
\hline Variabel & $\begin{array}{c}\text { Model } 1 \\
\text { OR } \\
(95 \% \mathrm{Cl})\end{array}$ & $\begin{array}{c}\text { Model } 2 \\
\text { OR } \\
(95 \% \mathrm{Cl})\end{array}$ & $\begin{array}{c}\text { Model } 3 \\
\text { OR } \\
(95 \% \mathrm{Cl})\end{array}$ & $\begin{array}{c}\text { Model } 4 \\
\text { OR } \\
(95 \% \mathrm{Cl})\end{array}$ \\
\hline \multicolumn{5}{|l|}{ Pola asuh } \\
\hline Permisif & $\begin{array}{c}3.63 \\
(1.12-11.76)\end{array}$ & $\begin{array}{c}3.03 \\
(0.90-10.18)\end{array}$ & $\begin{array}{c}2.72 \\
(0.81-9.16)\end{array}$ & $\begin{array}{c}2.37 \\
(0.69-8.15)\end{array}$ \\
\hline Otoritatif & $\begin{array}{c}2.54 \\
(0.84-7.66)\end{array}$ & $\begin{array}{c}2.03 \\
(0.65-6.36)\end{array}$ & $\begin{array}{c}1.91 \\
(0.61-5.99)\end{array}$ & $\begin{array}{c}1.57 \\
(0.48-5.13)\end{array}$ \\
\hline Demokratif & 1 & 1 & 1 & 1 \\
\hline \multicolumn{5}{|l|}{ Umur } \\
\hline Dewasa awal & & $\begin{array}{c}0.39 \\
(0.18-0.84)\end{array}$ & & $\begin{array}{c}0.41 \\
(0.19-0.91)\end{array}$ \\
\hline Dewasa madya & & 1 & & 1 \\
\hline \multicolumn{5}{|l|}{ Pendidikan } \\
\hline Rendah & & & $\begin{array}{c}2.56 \\
(1.14-5.73)\end{array}$ & $\begin{array}{c}2.38 \\
(1.05-5.41)\end{array}$ \\
\hline Tinggi & & & 1 & 1 \\
\hline$\underset{-2 \log \text { likelihood }}{N}$ & $\begin{array}{c}160 \\
166.824 \\
0.058\end{array}$ & $\begin{array}{c}160 \\
161.099 \\
0.109\end{array}$ & $\begin{array}{c}160 \\
161.437 \\
0.106\end{array}$ & $\begin{array}{c}160 \\
156.718 \\
0.147\end{array}$ \\
\hline
\end{tabular}

Hubungan Pola Asuh, Umur dan Pendidikan Ibu dengan Perkembangan

Hubungan pola asuh, umur dan pendidikan ibu dengan perkembangan anak gemuk usia 2-5 tahun digambarkan pada tabel 5 .

Berdasarkan hasil analisis pada tabel 5 model 4 , pola asuh permisif memiliki risiko 2 kali untuk terjadi suspek perkembangan (2.37 [0.69-8.15]). Jenis pola asuh bersama variabel pendidikan ibu memiliki peluang terjadinya suspek perkembangan pada sektor motorik kasar, motorik halus, bahasa dan personal sosial pada anak gemuk usia $2-5$ tahun sebesar $14.7 \%$ (R2 = 0.147).

Kemampuan perkembangan pada anak dapat dipengaruhi oleh lingkungan psikososial seperti stimulasi, motivasi belajar, lingkungan pengasuhan, ganajaran dan hukuman, kelompok teman sebaya, stres, sekolah, cinta kasih dan kualitas interaksi orang tua dan anak. Shanker dalam Yulita (2014), rumah, penghasilan, pekerjaan, pendidikan, pengalaman dan lingkungan sebelumnya merupakan faktor yang mempengaruhi perkembangan anak.

Blair et al, 2008; Shanker dalam Yulita (2014), adanya interaksi dengan manusia lain merupakan suatu hal yang sangat penting bagi seorang anak. Kontak mata, senyuman, memberikan kesempatan pada anak untuk berkomunikasi lebih lanjut, adanya pertukaran makna dalam komunikasi, adanya keterlibatan orang tua atau pengasuh akan membantu anak dalam mengembangkan dunianya untuk berhubungan dengan orang lain. 
Gaya yang digunakan orang tua saat berinteraksi, mendisiplinkan serta melakukan pengasuhan bersama (Benzies et al dalam Santrock, 2011b) memperlihatkan kualitas pengasuhan yang diberikan. Penelitian Rachmayanti dan Pudjiastuti (2012) menjelaskan bahwa pola asuh demokratis yang dilakukan orang tua dapat membantu anak melakukan tugas perkembangan sesuai usianya.

Penelitian Erwanto (2014) menyebutkan bahwa pola asuh otoriter memiliki peluang 27 kali untuk terjadinya sosialisasi anak kurang dibandingkan dengan pola asuh demokratis.

Myers dan Evans dalam Oktaviani (2008) menyatakan bahwa pendidikan berhubungan dengan tingkat pengetahuan seseorang. Pengetahuan orang tua yang terbatas dapat menyebabkan anak kurang atau bahkan tidak menerima stimulasi perkembangan yang cukup dan sesuai dengan tahapan usianya. Semakin tinggi pendidikannya diharapkan pengetahuan tentang perkembangan anak semakin baik sehingga dapat memberikan stimulasi baik fisik, sosial, emosional, maupun psikologis yang cukup bagi anak-anaknya.

\section{KESIMPULAN}

Jenis pola asuh ibu yang demokratif membantu anak melakukan tugas perkembangan $(p=0.009)$ dengan kekuatan hubungan lemah $(\rho=0.207)$. Pola asuh permisif pada anak gemuk usia 2-5 tahun memiliki peluang terjadi suspek perkembangan sebesar 2 kali $(2.37$; 0.69-8.15 $95 \% \mathrm{Cl}$ ). Pola asuh permisif yang dilakukan ibu dengan pendidikan yang rendah memiliki peluang terjadinya suspek perkembangan pada anak gemuk usia 2-5 tahun sebesar 14,7\% (R2=0,147).

\section{DAFTAR PUSTAKA}

Afriani A, Baharudin R, Nor S, Nurdeng. (2012). The relationship between parenting style and social responsibility of adolescents in Banda Aceh, Indonesia. Journal Of Social Sciences \& Humanities; 20(3): 736-7.

Blachman, D. R., \& Lukacs, S. (2009). America's Children: Key National Indicators of WellBeing. Annals of Epidemiology, 19(9), 667668.

Blair, Clancy \& Diamond, a. (2008). Biological Processes in Prevention and Intervention: The Promotion of Self-regulation as Means of Preventing School Failure. Development an Psychopathology. Vol. 20: h. 899-911.
Bornstein L \& Bornstein H. ( 2014). Parenting Styles and Child Social Development. Parenting skill. Encyclopedia on early childhood Development. 3rd ed. University of Pennsylvania, USA: National Institute of Child Health and Human Development.

Cawley, J., \& Spiess, C. K. (2008). Obesity and skill attainment in early childhood.Economics and Human Biology, 6(3), 388-397.

Chandriyani. 2009. Nilai Anak, Stimulasi Psikososial dan Perkembangan Kognitif Anak Usia 2-5 Tahun Pada Keluarga Rawan Pangan di Kabupaten Banjarnegara Jawa Tengah, [Skripsi] Bogor. Fakultas Pertanian. Institut Pertanian Bogor.

Drukker, M., Wojciechowski, F., Feron, F. J., Mengelers, R., \& Van Os, J. (2009). Acommunity study of psychosocial functioning and weight in young childrenand adolescents. International Journal of Pediatric Obesity, 4(2), 91-97.

Erwanto, Rizky. (2014). Hubungan Pola Asuh dengan Sosialisasi Anak Usia Prasekolah di Dusun Tempel Caturtunggal Depok Sleman Yogyakarta. Skripsi. Fakultas Kedokteran Universitas Gajah Mada Yogyakarta.

Griffiths, L. J., Parsons, T. J., \& Hill, A. J. (2010). Self-esteem and quality of life inobese children and adolescents: a systematic review. International Journal of Pediatric Obesity, 5(4), 282-304.

Hurlock (1999). Psikologi Perkembangan. Ed ke5. Jakarta: Erlangga

Jaenuddin E. (2000). Stimulasi Keluarga pada Perkembangan Bicara Anak Usia 6 sampai 36 Bulan di Kelurahan Kuningan, Semarang Utara. [dissertation]. Semarang (Indonesia): Universitas Diponegoro

Kemenkes RI. (2015). Profil Kesehatan Indonesia Tahun 2014. Jakarta: Sekretariat Jendral Kementrian Kesehatan Republik Indonesia.

Kusumanegara, Hari (2015). Hubungan antara Stimulasi Keluarga dengan Perkembangan pada Batita. Skripsi. Fakultas Kedokteran Universitas Diponegoro Semarang. Jawa Tengah.

Lopes VP, Stodden DF, Bianchi MM, Maia JA, Rodrigues LP., 2012. Correlation between $\mathrm{BMI}$ and motor coordination in children. $\mathrm{J}$ Sci Med Sport.15:38-43.

Morano, M., Colella, D., \& Caroli, M. (2011). Gross motor skill performance in asample of overweight and non-overweight preschool 
children. InternationalJournal of Pediatric Obesity, 6(S2), 42-46.

Novita, D. (2013) HUbungan Stimulasi Psikosoial di Rumah dan Proses Pembelajaran dengan Kecerdasan Majemuk Anak Taman Kanak-kanak di Kecamatan Pamulang Kota Tangerang. Tesis. Departemen IImu Keluarga dan Perkembangan Anak. Institut Pertanian Bogor.

Önder, A., \& Gülay, H. (2009). Reliability and validity of parenting styles \& dimensions questionnaire. Procedia - Social and Behavioral Sciences, 1(1), 508-514.

Pearce, A., Scalzi, D., Lynch, J., \& Smithers, L. G. (2016). Do thin, overweight and obese children have poorer development than their healthy-weight peers at the start of school? Findings from a South Australian data linkage study. Early Childhood Research Quarterly, 35, 85-94.

Pimpinan Pusat Muhammadiyah. (2016). Mushaf Al-Qur'an Al-Karim dan terjemah. Yogyakarta: Grama Surya

Pradipta, G. A. (2014). Keterlibatan orang tua dalam proses mengembangkan literasi dini pada anak usia paud di Surabaya. Journal Universitas Airlangga, 3(1), 1-2

Rahmayanti dan Pujiastuti. (2012). Hubungan Pola Asuh dengan Perkembangan Anak Usia Prasekolah di TK kartika x-9 Cimahi 2012. Skripsi. STIKes Jendral Achmad Yani.
Santrock, John W. (2011b). Life Span Development. 13th editions. New York: McGraw-Hill.

Sasroamoro, Sudigdo dan Ismael, Sofyan. (2014). Dasar-dasar Metodelogi Penelitian Klinis. Edisi ke-5. Jakarta: Sagung Seto.

Soetjiningsih dan Ranuh, G. (2012).Tumbuh Kembang Anak. Jakarta: EGC. Hal 14-71.

Stansbury K, Haley D, Holly E, Herb B. (2012). Adult caregivers' behavioral responses to child noncompliance in public settings: gender differences and the role of positive and negative touch. Behavior and Social Issues. 21: 80-2, 91-2.

Takahashi, Y., Okada, K., Hoshino, T., \& Anme, T. (2015). Developmental Trajectories of Social Skills during Early Childhood and Links to Parenting Practices in a Japanese Sample, 1-14.

Yulita, R. (2014). Hubungan Pola Asuh Orang Tua terhadap Perkembangan Anak BAlita di Posyandu Sakura Ciputat Timur. Skripsi. Fakultas IImu Keperawatan dan IImu Kesehatan Universitas Negeri Syarif Hidayatullah Jakarta.

Yusuf , A. ST. Hajrah. (2013) . Pengaruh Pola Asuh Orang Tua terhadap Tingkat Kooperatif Anak Usia 3-5 Tahun dalam Perawatan Gigi dan Mulut. Skripsi. Fakultas Kedokteran Gigi. Universitas Hasanuddin. Makasar. 